\title{
Novel Splicing, Missense, and Deletion Mutations in Seven Adenosine Deaminase-deficient Patients with Late/Delayed Onset of Combined Immunodeficiency Disease Contribution of Genotype to Phenotype
}

\author{
Ines Santisteban, “ Francisco X. Arredondo-Vega, ${ }^{*}$ Susan Kelly, ${ }^{\star}$ Ann Mary, * Alain Fischer, ${ }^{*}$ Donna S. Hummell, \\ Alexander Lawton, "3icardo U. Sorensen," E. Richard Stiehm, ' Lisa Uribe, * * \\ Kenneth Weinberg, ${ }^{\star *}$ and Michael S. Hershfield * \\ ${ }^{*}$ Department of Medicine, Duke University Medical Center, Durham, North Carolina $27710 ;{ }^{\ddagger}$ Department of Pediatrics, Hôpital Necker, \\ 75743 Paris, France; ${ }^{\S}$ Department of Pediatrics, Vanderbilt University, Nashville, Tennessee 37232; "Department of Pediatrics, \\ Louisiana State University, New Orleans, Louisiana 70112; 'Department of Pediatrics, University of California, Los Angeles, Los \\ Angeles, California 90024; and ** Division of Research Immunology, University of Southern California, Los Angeles, California 90027
}

\begin{abstract}
We examined the genetic basis for adenosine deaminase (ADA) deficiency in seven patients with late/delayed onset of immunodeficiency, an underdiagnosed and relatively unstudied condition. Deoxyadenosine-mediated metabolic abnormalities were less severe than in the usual, early-onset disorder. Six patients were compound heterozygotes; 7 of 10 mutations found were novel, including one deletion $(\Delta \mathbf{1 0 1 9 - 1 0 2 0})$, three missense (Arg156 > His, Arg101 > Leu, Val177 > Met), and three splicing defects (IVS 5, 5'ss $\mathrm{T}^{+6}>$ A; IVS 10, 5'ss G G $^{+1}$ $>$ A; IVS 10, $3^{\prime}$ ss G $^{-34}>$ A). Four of the mutations generated stop signals at codons $131,321,334$, and 348; transcripts of all but the last, due to $\Delta 1019-1020$, were severely reduced. $\Delta 1019-1020$ (like $\Delta 955-959$, found in one patient and apparently recurrent) is at a short deletional hot spot. Arg156 > His, the product of which had detectable activity, was found in three patients whose second alleles were unlikely to yield active ADA. The oldest patient diagnosed was homozygous for a single base change in intron 10 , which activates a cryptic splice acceptor, resulting in a protein with 100 extra amino acids. We speculate that this "macro ADA," as well as the Arg156 > His, Arg101 > Leu, Ser291 > Leu, and $\Delta 1019-1020$ products, may contribute to mild phenotype. Tissue-specific variation in splicing efficiency may also ameliorate disease severity in patients with splicing mutations. (J. Clin. Invest. 1993.92:2291-2302.) Key words: deletional hot spot • deoxyadenosine metabolism • genetic heterogeneity • pre-messenger RNA processing • severe combined immunodeficiency disease
\end{abstract}

\section{Introduction}

In $80-90 \%$ of cases, deficiency of adenosine deaminase $(\mathrm{ADA})^{1}$ results in severe combined immunodeficiency disease

Address reprint requests to Dr. Michael S. Hershfield, Box 3049, Duke University Medical Center, Durham, NC 27710.

Received for publication 20 May 1993 and in revised form 22 April 1993.

1. Abbreviations used in this paper: ADA, adenosine deaminase; dAdo, deoxyadenosine; dAXP, total deoxyadenosine nucleotides; PEG, poly-

J. Clin. Invest.

(c) The American Society for Clinical Investigation, Inc.

$0021-9738 / 93 / 11 / 2291 / 12 \$ 2.00$

Volume 92, November 1993, 2291-2302
(SCID) (1-3). Failure to thrive and life-threatening opportunistic infections begin in infancy and are associated with profound lymphopenia and absence of cellular and humoral immune function. Marked accumulation of dATP and loss of S-adenosylhomocysteine hydrolase (SAHase) activity in erythrocytes of these patients are specific consequences of impaired deoxyadenosine (dAdo) catabolism (4-7). In contrast to this dramatic and often fatal syndrome, about a dozen healthy children with normal immune function have been identified through population screening for erythrocyte ADA deficiency. They differ from SCID patients in having substantial residual ADA activity in nucleated cells ( so-called "partial" ADA deficiency), minimal elevation in erythrocyte dATP, and a different spectrum of ADA gene mutations ( reviewed in references 3 and 8). Nearly all of the ADA mutations reported to date have been from these two groups.

Two other phenotypes with intermediate severity have been recognized. In one, onset of serious infections is "delayed," beginning by about 6-12 mo of age. Humoral immunity may be less severely affected and infections, at least initially, less serious than in typical SCID patients; diagnosis is usually made by the age of $2-3 \mathrm{yr}$. The fourth group has a later clinical onset, few opportunistic infections, and gradual clinical and immunological deterioration. "Late" and "delayed" onset are somewhat arbitrary designations since age at onset may be difficult to pinpoint and patients with similar immunologic and clinical characteristics may be diagnosed at different ages depending on the experience of treating physicians. Nevertheless, it is estimated that $10-15 \%$ of ADA deficient patients have delayed onset (1-3). To date only four patients diagnosed beyond the age of 4 yr have been reported $(9,10$; Weinberg et al., manuscript in preparation). Because of their atypical features (and because ADA deficiency in any form is rare), lateonset patients are probably underdiagnosed. Indeed, some may be among patients with so-called "HIV-negative CD4 T lymphopenia with immunodeficiency of unknown etiology" (Weinberg et al., manuscript in preparation).

We have examined ADA gene mutations of four late- and three delayed-onset patients who are among a clinically diverse group (now $>40$ ) who have been treated with polyethylene glycol-modified bovine ADA (PEG-ADA) during the past $\sim 7$ $\operatorname{yr}(3,11,12)$. This report is part of a long-term study of this relatively large patient population, aimed at better defining the

ethylene glycol; SAHase, S-adenosylhomocysteine hydrolase; SCID, severe combined immunodeficiency disease. 
relationship of genotype to metabolic abnormality, clinical severity, and response to restoration of ADA activity (by enzyme replacement or gene therapy).

\section{Methods}

T cells were cultured from peripheral blood mononuclear cells as described (13) except that culture medium contained $15 \%$ heat-inactivated ( $30 \mathrm{~min}, 56^{\circ}$ ) fetal bovine serum (GIBCO, Laboratories, Grand Island, NY) and $50 \mathrm{U} / \mathrm{ml}$ IL-2 (Boehringer Mannheim Biochemicals, Indianapolis, IN) instead of $\mathrm{T}$ cell-conditioned medium.

Analysis of ADA gene mutations. Standard procedures were used for subcloning and restriction enzyme analysis (14) and for PCR (15, 16); recommendations of the suppliers of reagents used in these procedures were followed. Genomic DNA (17) and total cellular RNA (18) were prepared as described. First-strand cDNA was synthesized from 5 $\mu \mathrm{g}$ of total cellular RNA using a first-strand cDNA synthesis kit (Pharmacia Inc., Piscataway, NJ). PCR primers for ADA cDNA and genomic DNA are given in Table I. Wild-type ADA cDNA and genomic sequences are as reported $(19,20)$. ADA cDNA sequences are numbered relative to the start of translation and genomic DNA according to Wiginton et al. (20).

Reverse transcriptase-PCR was used to amplify a "full-length" ADA cDNA fragment extending from $61 \mathrm{bp} 5$ ' of the translation start codon to $311 \mathrm{bp} 3^{\prime}$ of the stop codon. In some cases a smaller fragment containing only the ADA coding region (bp 1-1091) was amplified. The PCR product was precipitated with isopropanol, treated with EcoRI and HindIII (IBI, New Haven, CT), purified on QIAEX (QIAGEN, Chatsworth, CA), and then subcloned into pUC18. Doublestranded DNA was sequenced with [ ${ }^{35}$ S]dATP (Amersham Corp., Arlington Heights, IL) using Sequenase (U.S. Biochemical, Cleveland). After gel purification, uncloned genomic DNA PCR products were sequenced using the cycle sequencing kit (Bethesda Research Laboratories, Rockville, MD) with ${ }^{32}$ P-end-labeled sequencing primers. For each patient, a minimum of six cDNA subclones containing the full coding region were sequenced to identify candidate mutations. For confirmation, PCR-amplified segments of genomic DNA were then analyzed by sequencing and where possible, restriction enzyme digestion, as described in Results. ${ }^{2}$

In vitro expression. "Full-length" mutant $\mathrm{ADA}$ cDNA subclones (after sequencing the entire coding region to establish that only the mutation of interest was present) were recloned into pBluescript SK+ (Stratagene, Inc., La Jolla, CA) and transcribed in vitro using T7 RNA polymerase to generate sense RNA. A similarly prepared full-length PCR fragment prepared from the normal ADA cDNA clone pADA211 (19) was used as a wild-type control. The size and yield of transcripts were verified on agarose-formaldehyde gels. An aliquot of the RNA was then used to prime a rabbit reticulocyte lysate translation system in the presence of [ $\left.{ }^{35} \mathrm{~S}\right]$ methionine (Promega Corp., Madison, WI). An aliquot $(5 \mu \mathrm{l})$ of the reaction was electrophoresed on cellulose acetate (Helena Labs, Beaumont, TX) and stained for ADA activity in situ, as described (13). The size of the ${ }^{35} \mathrm{~S}$-labeled translation product was analyzed by mercaptoethanol/10\% SDS polyacrylamide gel electrophoresis and fluorography, performed after treating the gel with Enhance (Dupont Co., Wilmington, DE). In experiments where immunoreactivity of the translation product was analyzed, aliquots of translation reactions were incubated at $4^{\circ} \mathrm{C}$ overnight in a volume of $0.5 \mathrm{ml}$ containing $2 \mu \mathrm{l}$ of goat anti-human ADA antibody (provided by Drs.

2. Sequencing gels documenting single-base changes in exons and previously reported mutations, which were provided for review, are not presented as figures in order to save Journal space. The authors will make the primary data available to interested readers.

Table I. PCR Primers

\begin{tabular}{|c|c|c|c|}
\hline & Primer sequence & Target* size (bp) & Cloning sites \\
\hline \multicolumn{4}{|l|}{ cDNA } \\
\hline "Full-length" & $5^{\prime}(+) 5^{\prime}$ TGCCAAGCTTAGCCGGCAGAGACCCACCGAG & -61 to 1402 & HindIII \\
\hline \multirow[t]{3}{*}{ coding region } & $3^{\prime}(-)$ 5'CTAGGAATTCGCATGCCACCAGCCATGG & $(1463 \mathrm{bp})$ & EcoRI \\
\hline & $5^{\prime}(+) 5^{\prime}$ CGCGCGAATTCATGGCCCAGACGCCCGCCTTCGAC & $1-1091$ & EcoRI \\
\hline & $3^{\prime}(-)$ 5'GCGCAAGCTTCAGAGGTTCTGCCCTGCAGAGGC & $(1091 \mathrm{bp})$ & HindIII \\
\hline \multirow[t]{2}{*}{ Exons 2-6 } & $5^{\prime}(+)$ 5'ATCAAGCCTGAAACCATCT & $64-556$ & \\
\hline & $3^{\prime}(-)$ 5'CATCTCCAGCCAGGT & (493 bp) & \\
\hline \multirow[t]{2}{*}{ Exons 5-11 } & $5^{\prime}(+) 5^{\prime}$ CCAGACGAGGTGGTGGC & $376-1001$ & \\
\hline & $3^{\prime}(-)$ 5'AAACTAGATTTGGCCGC & $(626 \mathrm{bp})$ & \\
\hline \multirow[t]{2}{*}{ Exons 9-11 } & $5^{\prime}(+)$ 5'ACACGGAGCATGCAGTCAT & $824-1031$ & \\
\hline & $3^{\prime}(-)$ 5'AGAAGCTCCCTCTTTTCATC & (208 bp) & \\
\hline \multicolumn{4}{|l|}{ Genomic } \\
\hline \multirow[t]{2}{*}{ Exon 4} & $5^{\prime}(+)$ 5'GCGGAAGCTTGGATGTCATTTGCTCCTG & 24899-25261 & HindIII \\
\hline & $3^{\prime}(-)$ 5'GCGCGAATTCCATCTTTCTGAGGCCATG & $(363 \mathrm{bp})$ & EcoRI \\
\hline \multirow[t]{2}{*}{ Exon 5} & $5^{\prime}(+) 5^{\prime}$ GCGG $A A G C T T C A A A G C C T C C T C T T C C T C$ & $25794-26169$ & HindIII \\
\hline & $3^{\prime}(-)$ 5'GCGCGAATTCAGGTCTCCAGTTGTTTCATG & (376 bp) & EcoRI \\
\hline \multirow[t]{2}{*}{ Exon 6} & $5^{\prime}(+)$ 5'TAGGCTGGGAGGTCTCTC & $27181-27496$ & \\
\hline & $3^{\prime}(-)$ 5'ACCCAACAAAGACACACTTC & $(316 \mathrm{bp})$ & \\
\hline \multirow[t]{2}{*}{ Exons 7-9 } & $5^{\prime}(+)$ 5'ATGCTGTTGAAGCAGGCAGCATGACTAGGA & $28376-29115$ & \\
\hline & $3^{\prime}(-)$ 5'TGCCTGCTTCCCAGGGTGTCGAAGAGATTT & $(740 \mathrm{bp})^{\ddagger}$ & \\
\hline \multirow[t]{2}{*}{ Exons $10-11$} & $5^{\prime}(+)$ 5'AGGCTGCTGTGAGGATCAAAGGCGGGTGAA & $30319-31340$ & \\
\hline & $3^{\prime}(-) 5^{\prime}$ TGCTAGAAGTCCCACAGAAAGCCACACTGG & $(1022 \mathrm{bp})^{\ddagger}$ & \\
\hline
\end{tabular}

Italics indicate cloning site. PCR reactions ( $50 \mu \mathrm{l})$ contained cDNA, primers (12.5 pmol each), 4 dNTPs (50 $\mu \mathrm{M}$ each), $3 \mathrm{U}$ of Hot Tub DNA polymerase, and buffer (Amersham Corp.). * cDNA numbered relative to start of translation; genomic DNA as in Wiginton et al. (20).

‡ After amplification (see reference 61), the 1022-bp product, spanning intron 9 to intron 11, was digested with PstI to yield a 849-bp fragment containing exons 10 and 11 and the intervening intron; this was subcloned into the PstI site of pUC18 prior to sequencing. 
Bruce Aronow and Dan Wiginton), or with nonimmune goat serum. The samples were then incubated for $2 \mathrm{~h}$ with $50 \mu \mathrm{l}$ of a $10 \%$ suspension of fixed staphylococcus A (Pansorbin, Calbiochem Corp., San Diego, $\mathrm{CA}$ ), and then centrifuged for $5 \mathrm{~min}$ in a microcentrifuge. The staph pellets were washed three times with NET-gel buffer (14) and then analyzed by SDS gel electrophoresis as above.

\section{Results}

\section{Patients}

Late onset. Patients AlNe, AnRo, AA (9, 21, 22), and CC (10, 12) were relatively asymptomatic until 2-5 yr of age, when recurrent respiratory problems, including sinusitis, bronchitis, asthma, and pneumonia became prominent features. By the time ADA deficiency was discovered at 5-15 yr of age (Table II), chronic pulmonary insufficiency was present to varying degree in AA, AlNe, and AnRo. At diagnosis all were T lymphopenic ( Table II); in vitro response of lymphocytes to mitogens was diminished and response to antigens was absent. Immunoglobulin levels and specific antibody responses to prior infection and immunization were variable. However, relatively well-preserved $\mathrm{T}$ cell function and humoral immunity had been documented $3 \mathrm{yr}$ before diagnosis in patients $\mathrm{AlNe}$ and AnRo (Weinberg et al., in preparation). Dysregulation of immunity and hematopoiesis were also present. AA had autoimmune thyroid insufficiency, $\mathrm{CC}$ had eosinophilia and a deficiency of the IgG2 subclass, and IgE was elevated in both CC and AlNe. At diagnosis AlNe was pancytopenic and transient pancytopenia and a hypocellular marrow were found in AnRo $3 \mathrm{yr}$ before diagnosis; the relationship to ADA deficiency is unclear.

Delayed onset. JH was diagnosed at the age of 14 mo when she presented with Pneumocystis carinii pneumonia and recurrent diarrhea from about 9 mo of age (23). AD was diagnosed at the age of 2 yr during evaluation for a persistent cough. She had been treated for pneumonia at $1 \mathrm{yr}$ of age and for nasal congestion and cough since the age of $3 \mathrm{mo}$, but she had never been hospitalized (12). AD developed transient autoimmune thrombocytopenia after a viral infection soon after diagnosis. $T$ lymphopenia ( Table II ) and reduced or absent lymphocyte responses to mitogens were found at diagnosis; immunoglobulin levels were variable but titers of specific antibody were low or absent.

MJ was discovered to be ADA deficient at the age of $3 \mathrm{yr}$ when she was evaluated for failure to thrive and chronic interstitial pneumonia. Lung biopsy showed extensive scarring with bronchiolitis obliterans; no etiologic agent was identified. Recurrent pulmonary infections and asthma dated from $1 \mathrm{yr}$ of age. Lymphopenia $\left(620 / \mathrm{mm}^{3}\right)$ was present at diagnosis without significant abnormalities in distribution of lymphocyte subsets. Mitogen responses of peripheral blood lymphocytes and quantitative immunoglobulins were normal, but antibodies to tetanus and diphtheria were absent despite adequate immunization. Delayed skin test reaction to tetanus toxoid was absent, but converted to positive on ADA replacement therapy, correlating with resolution of her lymphopenia.

Except for an unsuccessful trial of deoxycytidine infusion, intended to relieve inhibition of ribonucleotide reductase by dATP $(21,22)$, patient AA received no specific therapy aimed at restoring endogenous immune function until PEG-ADA was begun at the age $15 \mathrm{yr}, 7 \mathrm{yr}$ after diagnosis. The other patients began treatment with PEG-ADA at the time of diagnosis. All have shown sustained improvement in clinical status and immune function $(10,12,24)$ (and Weinberg et al., manuscript in preparation ). They all continue to receive PEG-ADA, including patients $\mathrm{CC}$ and $\mathrm{AD}$, who have also received experimental treatments with ADA gene-transduced T cells sporadically during the past 2-3 yr (12). MJ has required steroids and monthly immunoglobulin infusions $(1 \mathrm{~g} / \mathrm{kg}$ ) to control symptoms related to chronic bronchiolitis obliterans.

Table II. Clinical and Metabolic Characteristics

\begin{tabular}{|c|c|c|c|c|c|c|c|}
\hline \multirow[b]{2}{*}{ Patient } & \multicolumn{2}{|c|}{ Age } & \multirow{2}{*}{$\begin{array}{l}\mathrm{T} \text { cell } \\
\text { count }^{*}\end{array}$} & \multirow{2}{*}{$\begin{array}{l}T \text { cell } \\
\text { ADA }\end{array}$} & \multirow[b]{2}{*}{$\begin{array}{l}\text { Red cell } \\
\text { dAXP }\end{array}$} & \multirow[b]{2}{*}{$\begin{array}{l}\text { Red cell } \\
\text { SAHase }^{\ddagger}\end{array}$} & \multirow[b]{2}{*}{ References } \\
\hline & Diagnosis & Present & & & & & \\
\hline & & & cells/ul & $n m o l / h$ per $m g$ & $\mathrm{nmol} / \mathrm{ml}$ & $n m o l / h$ per $m g$ & \\
\hline $\operatorname{AlNe}(\mathrm{M}, \mathrm{H})$ & 15 & 16.3 & 397 & 87.2 & 60 & 1.01 & $\S$ \\
\hline $\operatorname{AnRo}(F, H)$ & 6 & 7.4 & 232 & 32.1 & 139 & 0.51 & $\S$ \\
\hline $\mathrm{AA}(\mathrm{F}, \mathrm{C})$ & 8 & 19.7 & $232 \pm 27$ & 15.7 & 264 & 0.56 & $(21)$ \\
\hline $\mathrm{CC}(\mathrm{F}, \mathrm{C})$ & 5.6 & 11.9 & 244 & 7.1 & 204 & 0.27 & $(10,12)$ \\
\hline $\mathrm{AD}(\mathrm{F}, \mathrm{A})$ & 2 & 6.7 & 26 & 24.3 & 289 & 0.26 & $(12)$ \\
\hline $\mathrm{JH}(\mathrm{F}, \mathrm{C})$ & 1.2 & 5.3 & $70-175$ & $\sim 1 \% \|$ & $253^{\pi}$ & $0.60^{* *}$ & (23) \\
\hline $\mathrm{MJ}(\mathrm{F}, \mathrm{C})$ & 3 & 4.7 & 423 & 12.1 & 218 & 0.67 & this report \\
\hline 12 early onset & $0.42 \pm 0.3$ & - & & $12.7-83.9$ & $797 \pm 426$ & $0.31 \pm 0.2$ & this report \\
\hline SCID patients & $0.1-0.9$ & & & (3 patients) & $354-1839$ & $0.03-0.86$ & \\
\hline Normal & & & $950-2600$ & $2047 \pm 1360$ & $<2$ & $4.18 \pm 1.2$ & \\
\hline
\end{tabular}

F, female; M, male; H, Hispanic; C, caucasian; A, Asian (Sri Lankan). dAXP = total dAdo nucleotides. ${ }^{*}$ At diagnosis: values are CD3 ${ }^{+}$cells except for AA (E-rosette $\left.{ }^{+}\right)$and $\mathrm{AD}\left(\mathrm{CD} 2^{+}\right)$; normal values are the approximate $95 \%$ confidence limits for caucasian adults; values are higher in children, depending on age. ${ }^{\ddagger}$ Pretreatment. ${ }^{\S}$ Weinberg, et al., manuscript in preparation. "In blood mononuclear cells. ' dATP (normal for lab $=$ undetectable). ${ }^{* *}$ Extrapolated from a reported value of $0.01 \mathrm{nmol} / \mathrm{min}$ per $\mathrm{mg}($ normal $=0.1 \pm 0.01 \mathrm{nmol} / \mathrm{m} \mathrm{per} \mathrm{mg})$. ${ }^{\ddagger} \mathrm{Untransfused}$ patients; data are from laboratory of Dr. Hershfield. 


\section{Metabolic status}

ADA activity in cultured T cells from six of the patients, and in uncultured blood mononuclear cells from $\mathrm{JH}$, ranged from $<1 \%$ to $\sim 4 \%$ of normal ( Table II). In pretreatment red cells, dAdo nucleotides ( dATP in the case of JH, total deoxyadenosine nucleotides (dAXP) in the other 6) ranged from 60 to 289 $\mathrm{nmol} / \mathrm{ml}$ (normal, $<2 \mathrm{nmol} / \mathrm{ml}$ ). These values are intermediate between those of typical SCID patients and healthy individuals with partial ADA deficiency. Among the latter AATP is $\leq 20 \mathrm{nmol} / \mathrm{ml}$ (reviewed in Hershfield and Mitchell [3]), while in 12 newly diagnosed, untransfused SCID patients ( samples analyzed at Duke University Medical Center), red cell dAXP ranged from $\sim 350$ to $>1800 \mathrm{nmol} / \mathrm{ml}$ (Table II). Erythrocyte SAHase activity ranged from $6 \%$ to $24 \%$ of normal, and exceeded $10 \%$ in five of the seven late/delayed-onset subjects. Among the 12 SCID patients, SAHase was $\leq 10 \%$ of normal in nine, and $<5 \%$ in six (Table II). AlNe, the oldest patient at diagnosis, had the mildest red cell metabolic abnormalities.

\section{ADA gene mutations}

Patient AlNe. All amplified cDNA subclones (8/8) had a 32bp insertion following bp 974 relative to the start of translation, precisely at the junction between exons 10 and 11 (Fig. $1 \mathrm{~A}$ ). The inserted sequence corresponded to the last 32 nucleotides of intron 10, suggesting a splicing defect. Direct sequencing of an amplified segment of genomic DNA spanning exons 10 and 11 revealed a previously unreported $G \rightarrow A$ transition in intron 10 at bp -34 relative to the normal intron 10 -exon 11 boundary, or at bp -2 relative to the start of the 32-base insert found in cDNA (Fig. $1 B$ ). No other base was incorporated at this position. The mutation introduces a new BfaI restriction site; digestion of the amplified exon 10-11 genomic fragment with Bfal showed only the mutant pattern, consistent with homozygosity (data not shown).

The $\mathrm{G}^{-34} \rightarrow$ A change converts a GG dinucleotide to AG, creating a new splice acceptor site with all the cis acting elements of a functional $3^{\prime}$ splice junction $(25,26)$ (Fig. $1 C$ ). Besides introducing nine new codons after Leu325, use of the cryptic splice site shifts the reading frame to include $268 \mathrm{bp}$ of the normal 3' noncoding region before a new TGA stop codon is generated $16 \mathrm{bp}$ from the polyA addition signal (Fig. $1 D$ ). The mutant protein is predicted to consist of 463 residues with a mass of $52,275 K_{\mathrm{d}}$, vs. 363 residues and $40,762 K_{\mathrm{d}}$ for the normal ADA protein. Although the normal $3^{\prime}$ splice site in intron 10 remains, the cryptic site is used preferentially in the patient's cultured T cells. Thus, no normal sized PCR product was detectable by ethidium bromide staining when a fragment spanning exons 10 and 11 was amplified from cDNA prepared from total T cell RNA (Fig. $1 E$ ).

Patient AnRo. Four cDNA subclones had a G > A transition at bp 529, which changes codon 177 (exon 6) from GTG Val to ATG Met, and introduces a new Ncol site (data not shown). Two subclones lacked this change, but had a deletion of the AG dinucleotide at bp 1019-1020 (exon 11) (Fig. $2 A$ ). Heterozygosity for these mutations was demonstrated by direct sequencing of exon 6 amplified from genomic DNA, and of amplified and subcloned genomic DNA spanning exons 10-11 (data not shown). Neither of these mutations has previously been reported.

$\triangle 1019-1020$ shifts the mRNA reading frame, changing amino acids 340-348 from KRELLDLLY to KGASRPALX, where X348 is a new TAA translation termination signal. Variable reduction in steady-state levels of transcripts bearing premature stop codons has frequently been observed (27-30). We estimate the level of the $\Delta 1019-1020$ transcript to be $30 \%$ to > $50 \%$ of that of the Vall 177 Met transcript. We infer this because two of six cDNA subclones had the deletion, and because the relative intensity of bands representing the two alleles generated by NcoI digestion of amplified CDNA was similar to that of the analogous bands generated from amplified genomic DNA (Fig. $2 B$ ).

Patient $C C$. Four amplified cDNA subclones possessed a $\mathrm{G}$ $>\mathrm{T}$ transversion at bp 302, changing Arg (CGG) to Leu (CTG) at codon 101 in exon 4 (data not shown). Four subclones lacked this change, but had a C $>\mathrm{T}$ transition at bp 872, which changes codon 291 from Ser (TCG) to Leu (TTG) in exon 10 (data not shown). Both mutations were confirmed by direct sequencing of amplified genomic DNA (data not shown). The Arg101 > Leu mutation has not been reported, but Ser291 > Leu has recently been identified independently (31).

Patient $A A$. Three amplified cDNA subclones possessed a previously unreported $\mathrm{G}>\mathrm{A}$ transition at bp 467 , which changes codon 156 in exon 5 from Arg (CGC) to His (CAC), and eliminates a recognition site for the isoschizomers HhaI and CfoI (data not shown). Four subclones lacked this change, but had a previously reported $\mathrm{G}>\mathrm{A}$ transition at bp 646, which causes the Gly216 > Arg substitution (exon 7) (32) (data not shown). Heterozygosity for each of these mutations in amplified genomic DNA was shown by the partial elimination of a HhaI/CfoI site in exon 5 and introduction of a new BstXI site in exon 7 (data not shown).

Figure 1. (A) Sequence of PCR amplified cDNA subclone from patient AlNe ( $M u t$ ) and a control ( $W t$, wild type) showing 32-bp insert (lower case) at the exon 10/exon 11 junction. $(B)$ Sequence of PCR-amplified genomic DNA from patient AlNe and a control showing the region of the intron 10/exon 11 junction. Stars indicate the site of the $G>A$ mutation $(C>T$ in the antisense sequence) at bp -34 from the normal intron/exon junction. Arrows indicate splice junctions. Nucleotides in the intron are in lower case and those included in mRNA in upper case. $(C)$ Comparison of the cryptic splice acceptor site in intron 10 in patient AlNe ( $M u t)$ and the normal ( Wt ) splice acceptor. Sequences are overlapped and numbered to show the regions involved in splicing; bp -34, the site of the G > A mutation (arrows), and bp 27-32 (underlined) indicate the sequence alignment. Intron nucleotides are in lower case and those included in mRNA in upper case. The box includes the T/CAG and polypyrimidine tract components of a consensus splice acceptor site. Stars indicate potential branchpoints. (D) Carboxy-terminal amino acid sequences for normal ( $W T$ ) ADA and patient AlNe ADA generated by use of the cryptic splice acceptor in intron 10. Nucleotides in the $3^{\prime}$ untranslated region $\left(3^{\prime} U T\right)$ are in lower case and the polyA addition signal is underlined. $(E)$ Ethidium bromide-stained agarose gel showing PCR-amplified cDNA spanning the exon 10/exon 11 boundary from patient AlNe (lane 1 ) and a normal control (lane 2). The 208 bp product is expected if the normal intron 10 splice acceptor is used and the 240 -bp product from use of the cryptic splice site generated by the patient's mutation. 


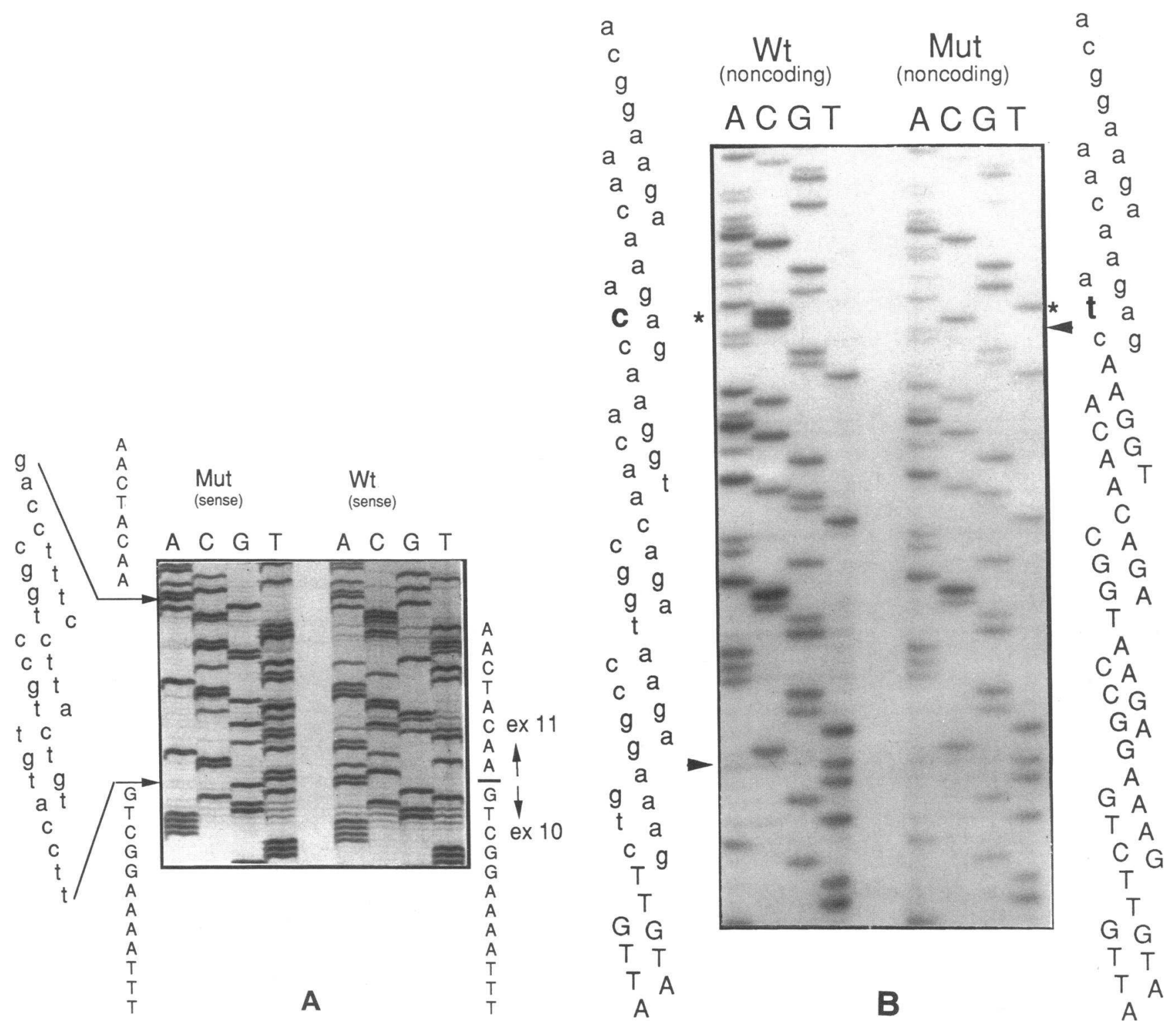

\section{C}

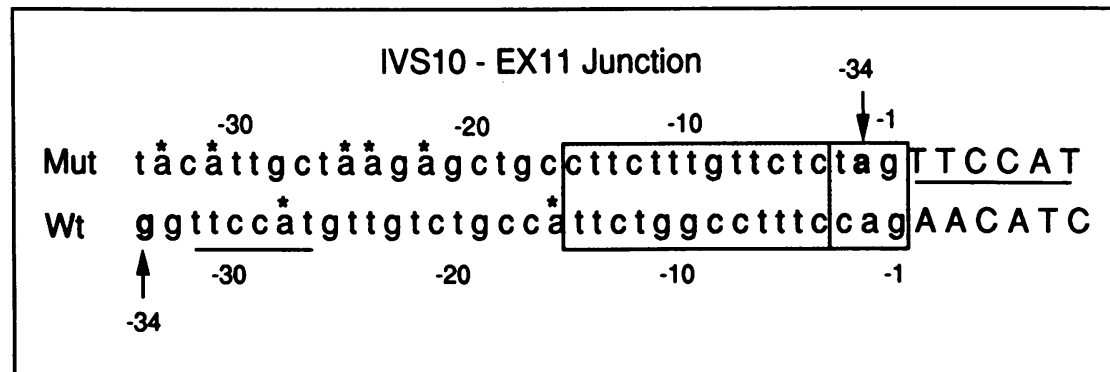
D WT ex 10|ex 11 321 EFKRLNINAA KSSFLPEDEK RELLDLLYKA YGMPPSASAG QNL* 364 3'UT ...268 bp...aa atctggtgct caataaagaa gcccatggct ggtggcatgc AlNe ex 10 ex 11
321 EFKRLFHVVC HSGRSRTSMR PNLVSSQKMK RGSFSTCSIK PMGCHLQPLQ 371 GRTSENATPP SLHPVESPQL CGAEQHFYIY SFQENHDLNS QLLMLLNPMC 421 PFLHTRIPRH GRVTSLIMCP GRDQRPCTWA WLNLKPSFCG NLY* 464 3'UT aa atctggtgct caataaagaa gcccatggct ggtggcatgC

E

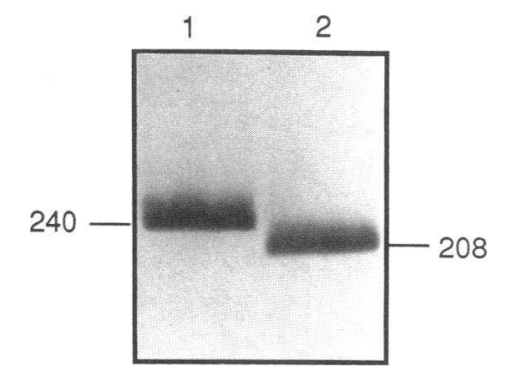




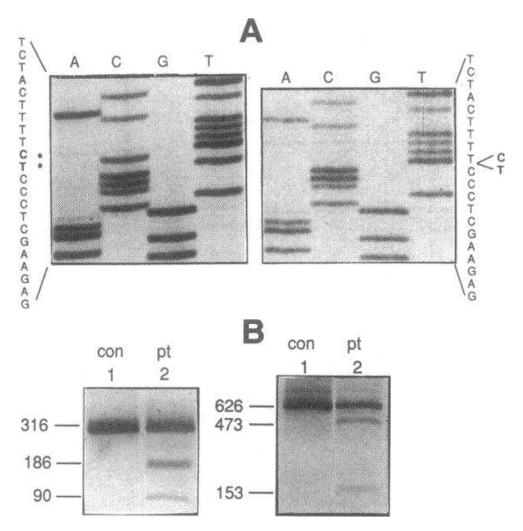

Figure 2. (A) Sequence (anti-sense) of PCRamplified cDNA subclones from a control (left panel) and patient AnRo (right panel) showing the region of exon 11. Stars indicate the $\mathrm{CT}$ dinucleotide (AG on coding strand) at position $1019-1020$ that are deleted. $(B)$ Ethidium bromide stained agarose gel of Ncol digested, uncloned PCR-amplified exon 6 from genomic DNA (left panel) and cDNA (right panel) from a control (con, lane 1) and patient AnRo ( $p t$, lane 2). The Val177 > Met mutation creates a new Ncol site and results in generation of bands at 186 and $90 \mathrm{bp}$ from the genomic DNA PCR product and 473 and $153 \mathrm{bp}$ from the cDNA PCR product.

Patients $J H$ and $M J$. CfoI digestion of exon 5 amplified from genomic DNA (Fig. 3, lanes 1-3) and direct sequencing (data not shown) showed that $\mathrm{JH}$ and $\mathrm{MJ}$ were each heterozygous for the Arg156 > His mutation found in patient AA. However, Cfol digestion of uncloned amplified cDNA prepared from $\mathrm{T}$ cells $(\mathrm{MJ})$ or fibroblasts $(\mathrm{JH})$ gave only the mutant pattern (Fig. 3, lanes 4-6), indicating that the second ADA allele in each case was either not expressed or was expressed at a very low level. Multiple cDNA subclones were then digested to identify any with Arg156 (wild type) as candidates for the second allele.

In the case of JH, 2 of $36 \mathrm{cDNA}$ subclones had Arg156. Both had a 4-bp insertion, ATGA, after bp 974, at the exon 10-11 junction (Fig. 4A). Direct sequencing of amplified genomic DNA revealed heterozygosity for $\mathrm{a} G>A$ transition at $b p$ +1 of intron 10 , changing the wild-type splice donor sequence from gtgagt to atgagt (Fig. $4 \mathrm{~B}$ ). Mutations of the invariant $\mathrm{G}^{+1}$ to A can cause skipping of a preceding exon or can activate downstream or upstream cryptic splice donor sites (33-35). In

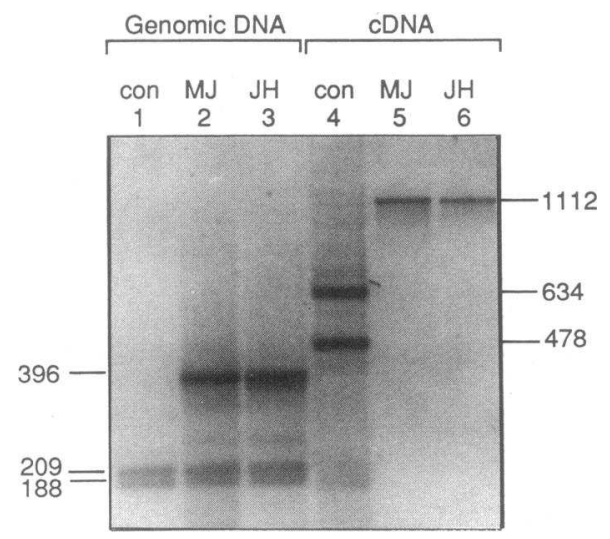

Figure 3. Ethidium bromide stained agarose gel of Cfol digested, uncloned PCR-amplified exon 5 from genomic DNA (lanes 1-3) and cDNA (lanes 4-6) from a control (lanes 1 and 4) and patients MJ (lanes 2 and 5) and $\mathrm{JH}$ (lanes 3 and 6). The Arg156 > His mutation eliminates a CfoI site and results in loss of bands at 209 and $188 \mathrm{bp}$ from the genomic DNA PCR product and at 634 and $478 \mathrm{bp}$ from the cDNA PCR product.
JH fibroblasts use of a cryptic splice donor at $b p+5$ of intron 10 (gtgggt) results in inclusion of the first four intronic bp (including the mutation) in mRNA. As a result, amino acids 326-334 at the start of exon 11 are changed from the wild-type NINAAKSSF to MKHQCGQIX. The new TAG stop signal at codon 334, which eliminates 30 carboxy-terminal residues, apparently accounts for the very low abundance of the corresponding mRNA.

In the case of MJ, 1 of $28 \mathrm{cDNA}$ subclones analyzed lacked the mutation at codon 156. Sequencing revealed a deletion in exon 10 of GAAGA, bp 955-959 from the start of translation (data not shown). Heterozygosity for this 5-bp deletion was demonstrated by sequencing subclones of amplified exon 10 genomic DNA, and by showing heterozygosity for a new BpmI site in the uncloned genomic PCR product (data not shown). This deletion shifts the reading frame and mutates codons 319321 from EEE to GVX, eliminating the last 43 amino acids. This same 5-bp deletion has recently been found in a patient with early-onset $\mathrm{SCID}^{3}$ and in unrelated ADA-deficient patients (36). MJ lacks a polymorphism, Lys80 > Arg, found in one of these patients, suggesting an independent origin, consistent with the suggestion that the mutation is at a deletional hot spot. $^{3}$

Patient $A D$. BstXI digestion of exon 7 amplified from genomic DNA showed that AD was heterozygous for the Gly216 $>$ Arg mutation (data not shown). Of 20 cDNA subclones analyzed, 17 were mutant and 3 wild type at codon 216 . The latter in each case lacked exon 5, with precise joining of exon 4 to exon 6 (Fig. $5 \mathrm{~A}$ ). Complete sequencing of one full-length cDNA clone missing exon 5 revealed no other mutations. These findings suggested a mutation that affected splicing of exon 5. Direct sequencing of amplified genomic DNA revealed wild-type exon 4 /intron 4 , intron 4 /exon 5 , and intron 5 /exon 6 junctions, and there were no changes in exon 5 . However, at $\mathrm{bp}+6$ of intron 5 both $\mathrm{A}$ and the normal $\mathrm{T}$ were present (gtgagt/a). The intron $5 \mathrm{~T}^{+6}>\mathrm{A}$ transversion was subsequently found in 5 of 10 subclones derived from the amplified genomic segment (Fig. 5 B).

Loss of exon 5 shifts the ADA mRNA reading frame, changing the amino acid sequence after codon 121 and creating a TAA stop signal at codon 131 . To estimate the abundance of mRNA lacking exon 5, a segment spanning exons 2-6 was amplified from cDNA prepared from AD T cells and analyzed on an agarose gel. The normal-sized product was obtained, but no band of the size expected for deletion of exon 5 was detected by ethidium bromide staining, indicating very low abundance (data not shown).

\section{ADA activity of mutant proteins expressed in vitro}

In vitro translation of RNA transcribed from cDNA, combined with in situ assay for ADA activity, was used to determine whether the putative mutations identified were capable of causing ADA deficiency. Equal amounts of mutant and wildtype translation products were compared in the in situ assay. In the experiment shown in Fig. 6, the Val177 > Met, $\Delta 1019$

3. Gossage, D. L., C. J. Norby-Slycord, M. S. Hershfield, and M. L. Markert. 1993. A homozygous five nucleotide deletion in the adenosine deaminase (ADA) mRNA in a child with ADA deficiency and very low levels of ADA mRNA and protein. Hum. Mol. Genet. In press. 

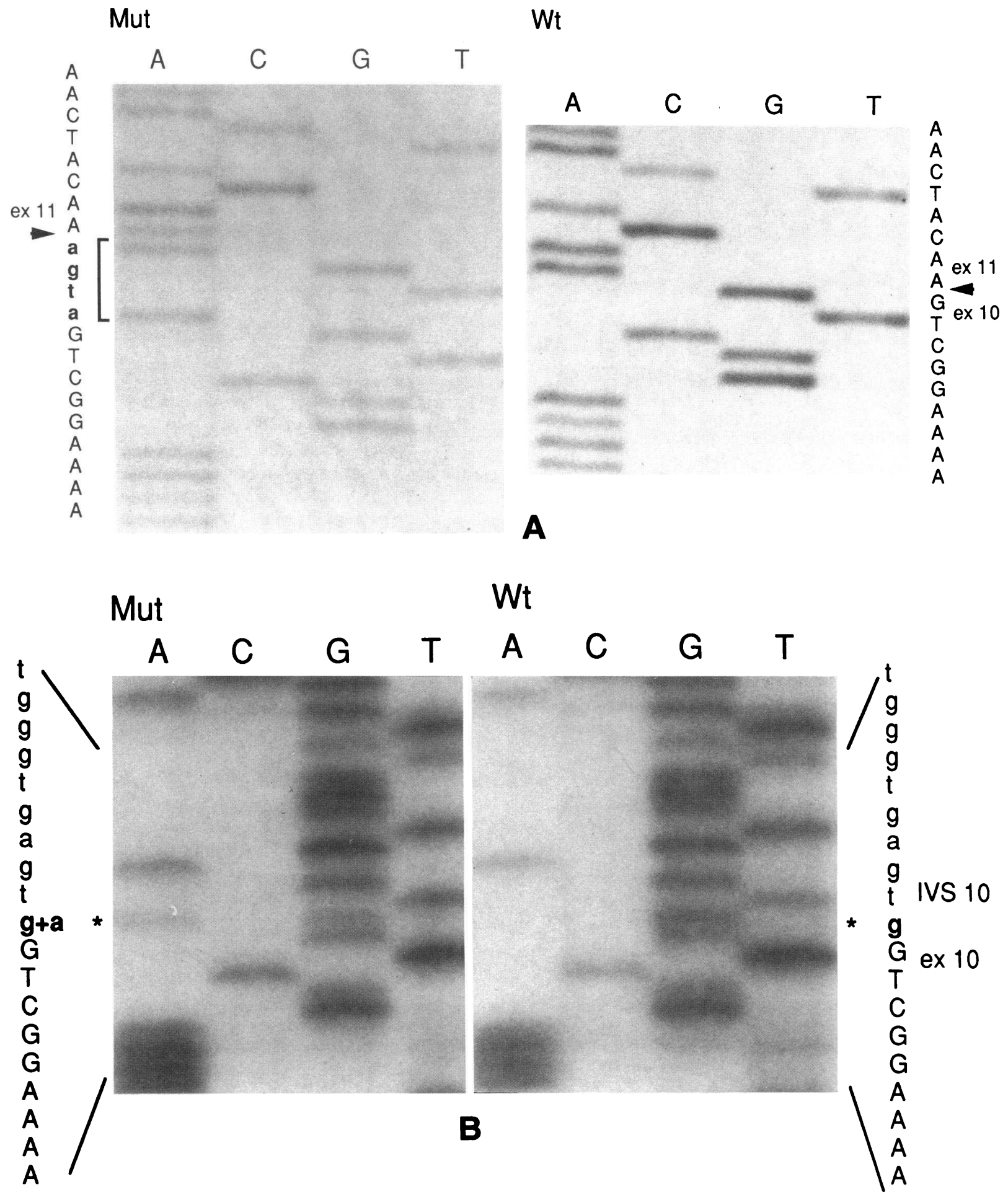

Figure 4. (A) Sequence (sense) of PCR-amplified cDNA subclone from patient JH (left panel) and a control (right panel) in the region of the exon 10/exon 11 junction. JH has a 4-bp insertion (bold, lower case). (B) Sequence (sense) of PCR-amplified, uncloned genomic DNA from patient $\mathrm{JH}$ (left panel) and a control (right panel) in the region of the exon 10/intron 10 junction showing the presence of both a $\mathrm{G}$ and $\mathrm{A}$ at position +1 of the splice donor site in intron 10 (star). Intron nucleotides are in lower case and exon nucleotides in upper case.

1020, Arg $101>$ Leu, Ser291 > Leu, and Arg156 > His cDNAs were tested. The major band generated from the wild-type transcript and from mRNAs with amino acid substitutions migrated just ahead of the ovalbumin ( $46 \mathrm{kD}$ ) marker (Fig. $6 \mathrm{~A}$ ). The major $\Delta 1019-1020$ product was smaller, consistent with the predicted truncation at codon 348 . Two smaller ${ }^{35}$ S-labeled translation products were generated from wild-type and mutant transcripts. They were not produced in the absence of mRNA and are presumably due to aberrant translation or to proteolysis.

ADA activity of the wild-type translation product was easily detected by in situ staining after electrophoresis on cellulose 
A
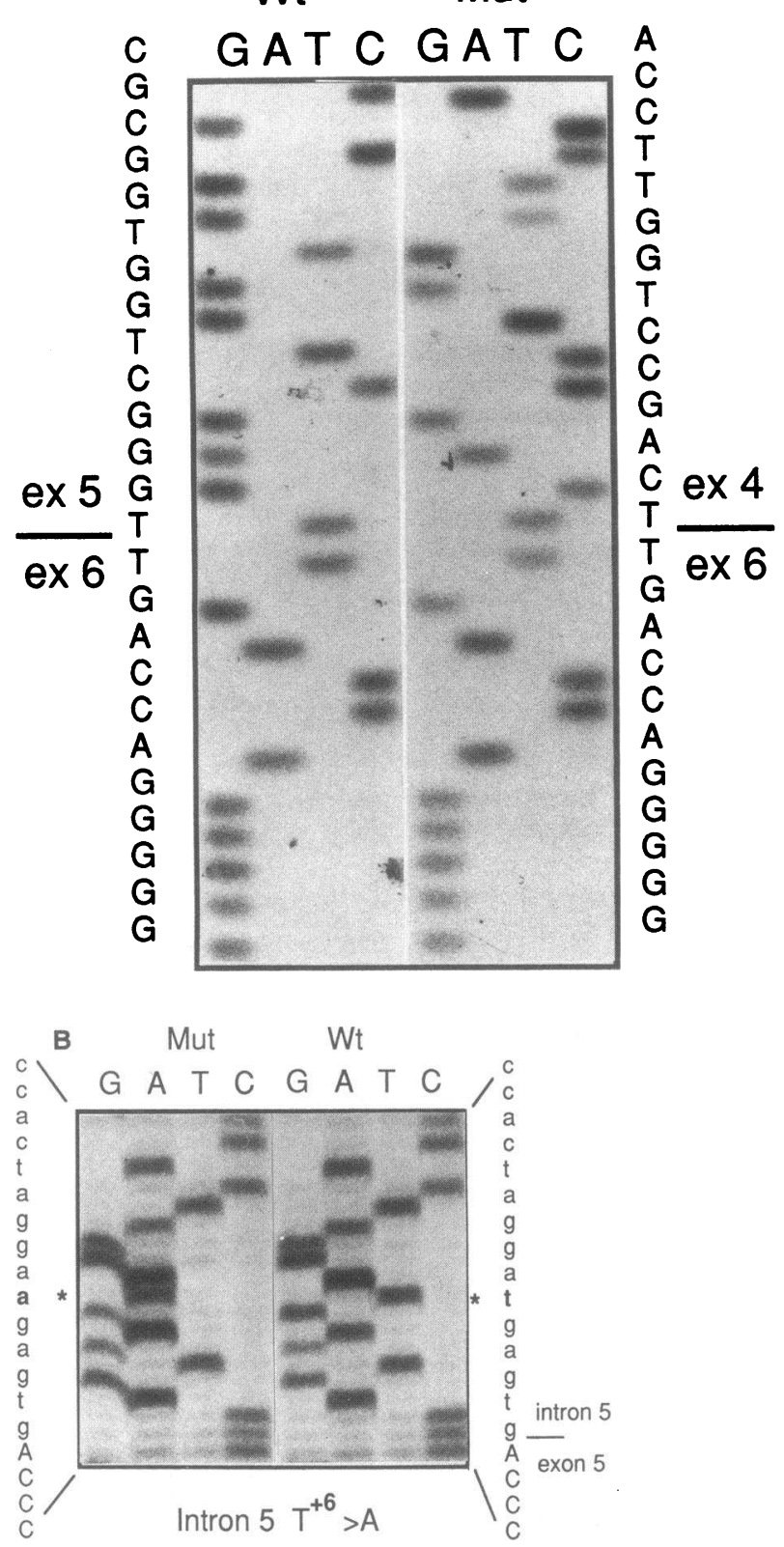

Figure 5. (A) Sequence (anti-sense) of PCR-amplified cDNA subclone spanning exons 4-6 from a control (left panel) and patient AD (right panel) showing deletion of exon 5 in the patient. (B) Sequence (sense) of PCR-amplified genomic DNA subclone in the region of the exon 5 /intron 5 junction from patient $\mathrm{AD}$ (left panel) and a control (right panel) showing a $\mathrm{T}>\mathrm{A}$ transversion at position +6 of the splice donor site (star). Intron nucleotides are in lower case and exon nucleotides in upper case.

acetate (Fig. $6 \mathrm{~B}$ ). Of the mutants tested, only the Arg156 $>$ His product (lane 8 ) showed detectable ADA activity, and this was much fainter than for the wild-type translation product; this result was reproducible. In other experiments not presented, no activity was detected with the Gly216 > Arg in vitro translation product, consistent with transient expression studies in cos cells (32). The translation product derived from the intron $10 \mathrm{G}^{+1}>$ A splice donor mutation $(\mathrm{JH})$, which is truncated at codon 334, was of the expected size and was also inactive (data not shown).

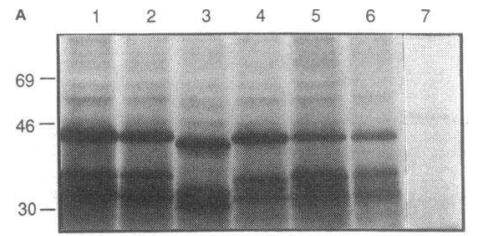

Figure 6. ( $A$ ) SDS-mercaptoethanol gel of ${ }^{35} \mathrm{~S}$ labeled in vitro translation products. See Methods for details of procedure. Lane 1, normal human ADA; lane 2, patient AnRo Val177

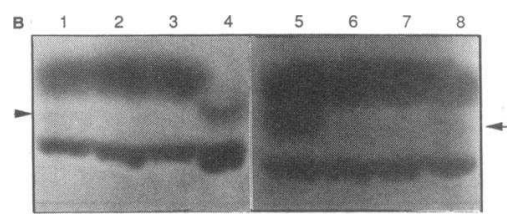

$>$ Met; lane 3, patient

AnRo $\Delta 1019-1020$,

lane 4, patient $\mathrm{CC}$

Arg101 > Leu; lane 5, patient CC Ser291

$>$ Leu; lane 6, patient

AA, Arg156 > His; lane

7, no RNA control. Numbers at left, size ( $k D)$ of molecular mass markers. $(B)$ In situ ADA assay of in vitro translation products. See Methods for details of procedure. Arrows indicate position of human ADA. The dark bands at the bottom and top (lanes 1-3 and 5-8) are rabbit hemoglobin and rabbit ADA, respectively, carried over from the reticulocyte translation reaction. Lane 1, no RNA control; lane 2, patient AnRo Val177 > Met; lane 3, patient AnRo D1019-1020, lane 4, human erythrocyte lysate (lower band is hemoglobin); lane 5, normal human ADA; lane 6, patient CC Ser291 > Leu; lane 7, patient CC Arg101 > Leu; lane 8, patient AA, Arg156 > His.

The major translation product derived from AlNe cDNA, which is predicted to have 100 more amino acid residues than wild type ADA, had an estimated mass of $57-58 \mathrm{kD}$ (Fig. $7 A$ ). Although this is larger than the $52 \mathrm{kD}$ expected, the wild-type translation product was also larger than expected on this gel, $\sim 46 \mathrm{kD}$ instead of $41 \mathrm{kD}$. Both the mutant and wild-type ${ }^{35}$ S-labeled peptides were specifically precipitated with antibody to human ADA (Fig. 7 B). ADA activity of the mutant translation product was undetectable (Fig. $7 \mathrm{C}$, left panel). However, sufficient activity was present in extracts of AlNe T cells to detect by in situ assay. The activity, presumably derived from mRNA generated by use of the cryptic $3^{\prime}$ splice site, migrated more slowly than wild-type ADA (Fig. 7 C, right panel). Further characterization of this "macro-ADA" will be reported elsewhere.

\section{Discussion}

Among the seven patients studied, all 14 chromosomes were accounted for and 10 different mutations were identified. These included two short deletions and five missense mutations located in exons 4, 5, 6, 7, 10, and 11 ; and three splicing defects in introns 5 and 10 (Table III). One of the deletions, three of the amino acid substitutions, and the three splicing defects are novel. In vitro translation products bearing the new mutations lacked or had much less enzymatic activity than an equivalent amount of wild-type translation product, evidence that the mutations cause ADA deficiency. Further studies of expression of cloned cDNAs in intact cells and of purified, overexpressed enzymes will be needed to assess the stability and kinetic properties of the mutant proteins, and their contribution to residual cellular ADA function.

Environmental factors and circumstances (exposure to specific organisms, the nature of medical care, whether a patient is the first or second affected child in a family, etc.) are important in determining disease severity in patients with ADA deficiency. Also, given the complex nature of immunity and resis- 
A

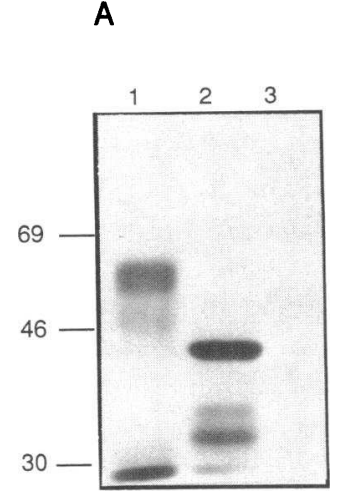

B
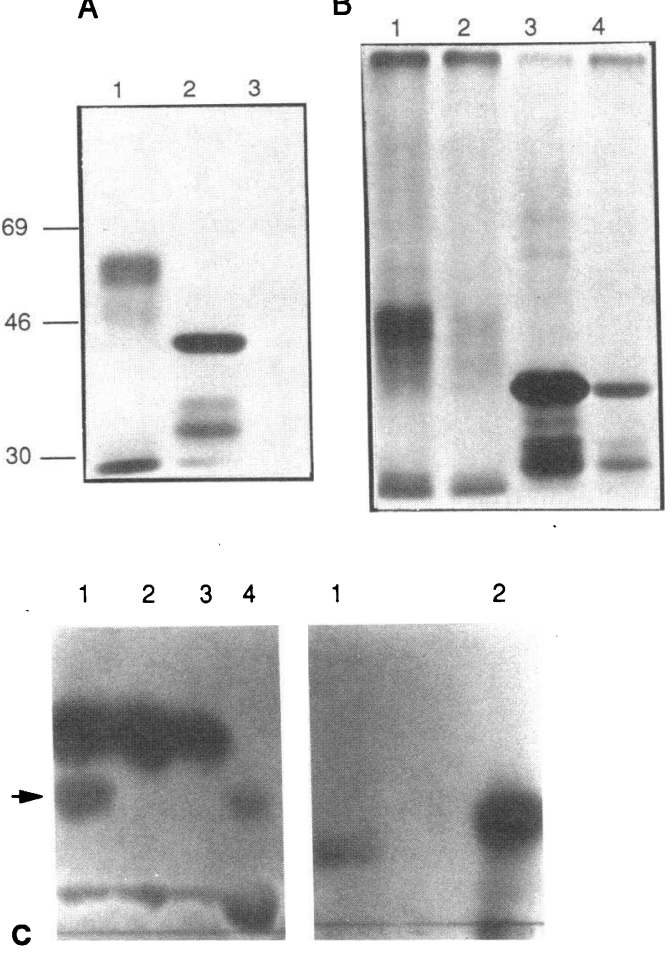

Figure 7. $(A)$ SDS gel of ${ }^{35}$ S-labeled in vitro translation products. Lane 1, patient AlNe; lane 2, normal human ADA; lane 3, no RNA control. (B) SDS gel of ${ }^{35}$ S-labeled translation products from the experiment shown in $A$ after immunoprecipitation with goat antihuman ADA antibody (lanes 1 and 3 ) or nonimmune goat serum (lanes 2 and 4) (see Methods). Lanes 1 and 2, AlNe; lanes 3 and 4 , normal human ADA. (C) In situ ADA assay. Left panel: translation products from the experiment shown in $A$. Lane 1 , normal human ADA; lane 2, patient AlNe; lane 3, no RNA control; lane 4, human erythrocyte lysate. Right panel: $\mathrm{T}$ cell extracts from patient AlNe (lane 1 ) and a normal control (lane 2). Extracts were prepared from $2 \times 10^{6}$ control T cells and $2 \times 10^{7}$ AlNe T cells by freezing and thawing three times. After centrifugation, 3- $\mu$ l aliquots were electrophoresed on cellulose acetate and stained for ADA activity as for assay of translation products. tance to infection, it is likely that genes other than ADA can influence clinical phenotype in patients with ADA deficiency. Nevertheless, a simple hypothesis, based on the known metabolic consequences of ADA deficiency ( 3 ), is that specific ADA mutations affect phenotype insofar as they determine the overall capacity to eliminate dAdo, the primary lymphotoxic ADA substrate.

There is evidence that the capacity to eliminate dAdo is related to disease severity. Specifically, the degree of dAXP pool expansion and SAHase inactivation in erythrocytes reflect exposure to circulating dAdo (red cells lack dAdo precursors), and hence total residual ADA function (discussed in Hershfield and Mitchell [3]). Abnormalities in these parameters in the late/delayed-onset patients under study were less marked than in typical SCID patients, but more severe than in individuals with partial ADA deficiency ( see Results), consistent with the working hypothesis. An important corollary of this hypothesis is that, in conferring a mild phenotype, an allele that provides some functional ADA will be dominant to one that eliminates function. This simplifies evaluation of the contribution of individual mutations to disease severity in compound heterozygotes, i.e., six of the seven patients studied.

The Arg156 > His mutation found in patients AA, MJ, and $\mathrm{JH}$, had detectable in situ ADA activity. It is very unlikely that the second alleles of these patients are functional. The 5-bp deletion in the case of $\mathrm{MJ}$, and the invariant $\mathrm{G}^{+1}$ splice donor mutation in the case of $\mathrm{JH}$, resulted in proteins predicted to be truncated by 43 and 30 carboxy-terminal amino acids, respectively, and in each case very low levels of the corresponding mRNA were detected. The second mutation in late onset patient AA (and also in delayed onset patient AD) is Gly216 $>$ Arg. Homozygosity for this mutation was found in a single patient with a very severe phenotype (32). Our experience with other patients, to be presented elsewhere, confirms that Gly216 $>\mathrm{Arg}$, when it is the only expressed allele, is associated with severe metabolic abnormalities and early-onset SCID. It is noteworthy that the Arg156 > His mutation occurs at a CpG mutational hot spot $(37,38)$. The fact that it has been found in three patients with delayed or late onset and none with the more

Table III. Sumary of Mutations Identified

\begin{tabular}{|c|c|c|c|c|}
\hline Patient & Location (bp) & Mutation & Effect of mutation & Restriction site affected ${ }^{*}$ \\
\hline $\mathrm{AlNe}$ & IVS $10(31,131)$ & 3 'ss $-34 \mathbf{G}>\mathbf{A}$ & $\begin{array}{l}\text { 32-bp insert in mRNA; } \\
\text { adds } 100 \text { amino acids }\end{array}$ & BfaI $(+)$ \\
\hline \multirow[t]{2}{*}{ AnRo } & exon $11(1019-20)$ & $\mathrm{A}[\mathbf{A G}] \mathrm{AGG}^{\ddagger}$ & premature stop codon 348 & - \\
\hline & exon $6(529)$ & GTG $>$ ATG & Val177 > Met & $\operatorname{Ncol}(+)$ \\
\hline \multirow[t]{2}{*}{$\mathrm{CC}$} & exon $4(302)$ & CGG $>$ CTG & Arg $101>$ Leu & - \\
\hline & exon $10(872)$ & TCG $>$ TTG & Ser $291>$ Leu & - \\
\hline \multirow[t]{2}{*}{ AA } & exon $5(467)$ & $\mathrm{CGC}>\mathrm{CAC}$ & $\operatorname{Arg} 156>\mathrm{His}$ & Hhal, Cfol (-) \\
\hline & exon $7(646)$ & GGG $>$ AGG & Gly $216>$ Arg & BstXI (+) \\
\hline \multirow[t]{2}{*}{ JH } & exon $5(467)$ & $\mathrm{CGC}>\mathrm{CAC}$ & $\operatorname{Arg} 156>$ His & Hhal, Cfol (-) \\
\hline & IVS $10(30,549)$ & $\begin{array}{l}5^{\prime} \text { 'ss } \\
\mathbf{G}^{+1}>\mathbf{A}\end{array}$ & $\begin{array}{l}4 \text { bp insert in mRNA; } \\
\text { premature stop codon } 334\end{array}$ & HphI (-) \\
\hline \multirow[t]{2}{*}{ MJ } & exon $5(467)$ & $\mathrm{CGC}>\mathrm{CAC}$ & $\operatorname{Arg} 156>$ His & Hhal, CfoI (-) \\
\hline & exon $10(955-59)$ & CT [GAAGA] GG $^{\ddagger}$ & premature stop codon 321 & BpmI (+) \\
\hline $\mathrm{AD}$ & $\begin{array}{l}\text { IVS } 5(26,009) \\
\text { exon } 7(646)\end{array}$ & $\begin{array}{l}5^{\prime} \mathbf{s S ~ T}^{+6}>\mathbf{A} \\
\mathbf{G G G}>\mathbf{A G G}\end{array}$ & $\begin{array}{l}\text { skip exon } 5 \\
\text { Gly2 } 16>\operatorname{Arg}\end{array}$ & BstXI (+) \\
\hline
\end{tabular}

${ }^{*}(+)$, site created by mutation; $(-)$, site eliminated by mutation. ${ }^{\ddagger}$ Bases in brackets deleted. 
common SCID presentation further supports the conclusion that it confers a relatively mild phenotype. Although Arg156 $>$ His has not previously been reported, substitution of Cys for Arg 156 has been found in a SCID patient who responded transiently to partial exchange transfusion (31). Response to the relatively low level of ADA activity provided by this treatment was considered unusual and an indication of relatively mild disease.

Either of the alleles possessed by CC, Arg101 > Leu and Ser291 > Leu, could contribute to her mild metabolic and clinical phenotype. Ser291 > Leu has been identified independently in an ADA-deficient SCID patient, who showed improvement during red cell transfusion therapy (31). Arg101 $>$ Leu has not yet been found in other patients, but Arg101 $>$ Gln was apparently the only allele expressed in a patient with mild disease (39-41). Arg101 > Trp was found in a SCID patient whose second mutation was Arg211 > His (42). Cultured $T$ cells from this patient were found to express significant levels of ADA activity, though it was unclear which allele was responsible for this activity (13).

Neither Val177 > Met nor $\Delta 1019-1020$ found in late onset patient AnRo have previously been described; either one, or the combination, could provide sufficient enzymatic activity to diminish disease severity. $\Delta 1019-1020$ in exon 11 changes seven of eight amino acids after codon 341 and terminates translation at codon 348 , eliminating the last 16 residues. However, abundance of the mRNA for this allele was not as severely reduced as with the frame shifting alleles of patients $A D, M J$, and $\mathrm{JH}$, which generate premature stop signals at codons 131 , 321 , and 334, respectively. This is consistent with polarity effects of premature stop signals on mRNA stability for other genes $(28-30,43)$. No point mutations responsible for ADA deficiency have been reported beyond Ala 329. Moreover, wild-type murine ADA, which otherwise is highly homologous, is 11 amino acids shorter than human ADA, and the "missing" residues are all at the carboxy terminus (44). Based on the crystal structure of murine ADA (45), the carboxy terminal residues affected by $\Delta 1019-1020$ should be located far from the active site.

It is noteworthy that $\Delta 1019-1020$ lies within $60 \mathrm{bp}$ of $\Delta 955-959$ found in MJ. Each occurs in a segment that contains multiple short direct repeats, a motif that appears to predispose to short deletions, and each is part of a sequence that resembles a consensus short deletional hot spot, TGA/GA/GG/TA/C (46). Thus, as has been noted, ${ }^{3}$ the $\Delta 955-959$ segment, TTTAGTgaagaGGAGTTTA (deleted bases in lower case), has three GA and a TTTA repeat (underlined). Similarly, the 1019-1020 segment, AGAAGATGAAAagGGAG, has four $A G$ repeats and is part of an AAG repeat. If $\Delta 1019-1020$ is a hot spot, it will be interesting to see whether it occurs selectively in patients with late or delayed onset rather than early onset SCID.

AlNe is homozygous for $\mathrm{a} G>A$ mutation at bp -34 from the intron $10 / 11$ junction. The cryptic splice acceptor activated by this mutation was highly favored over the normal site in his cultured $T$ cells. A number of local and long-range "context" factors govern selection among alternative splice sites $(47,48)$. In the present case, the cryptic splice site has five A residues located $22-33$ bp $5^{\prime}$ of the new splice junction that might be used as a branchpoint; the wild-type splice acceptor for intron 10 has only two, at -16 and $-28 \mathrm{bp}$ (Fig. 1C). Use of the cryptic splice site results in an enzyme 100 amino acids longer than normal. Preliminary studies (A. Mary and M. S. Hershfield, unpublished observation) suggest that the mutant enzyme accounts for the residual ADA activity detected in T cells of the patient. Whether it accounts entirely for his quite mild metabolic abnormality and remarkable survival to the age of $15 \mathrm{yr}$ before diagnosis remains to be determined. A low level of normal enzyme may be generated by use of the normal splice site in some cell types. In this regard, tissue and patientspecific variation in splicing efficiency appear to account for the variable phenotype associated with an unusual splicing mutation in the HexB gene (49). Differences in nuclear processing of pre-mRNA have been postulated to play a role in regulating ADA levels in certain cell lines (50), though whether or not splicing is involved is unclear.

In the case of $\mathrm{AD}$, skipping of exon 5 results from the splice donor mutation $\mathrm{T}^{+6}>\mathrm{A}$ in intron 5. Skipping of a preceding exon due to splice donor site mutations has been observed in patients with several other genetic disorders (51-57). This finding may be explained by the "exon definition" model (58), in which the splicing machinery first binds at a $3^{\prime}$ splice acceptor site, then searches downstream for a 5 ' splice site; definition of the exon is then followed by rearrangement of the splicing components to allow intron removal. In this model, if a splice acceptor site is not followed within $\sim 300$ bp by a proper $5^{\prime}$ splice donor site the exon is deleted or a cryptic splice donor site in the exon may be used, as in the case of a bp +6 mutation in IVS 1 of the $\beta$-globin gene $(59,60)$. Inspection of ADA exon 5 shows a potential, though nonconsensus splice donor site, AGgtggtg, at bp 21-28 from the 5' end, which apparently is not used in the cells of patient AD.

Skipping of exon 5 markedly destabilizes the corresponding mRNA and results in a protein truncated at codon 131, which is undoubtedly inactive. As discussed above, AD's second mutation, Gly216 > Arg is unlikely to contribute to her mild phenotype. It is possible that factors other than ADA genotype are involved. However, as discussed for $\mathrm{AlNe}$, it is possible that correct splicing at exon 5 occurs in some cell type(s), providing sufficient dAdo catabolizing activity to ameliorate disease. In this regard the +6 mutation in $\beta$-globin allowed some normal processing to occur and resulted in a mild $\beta+$ thalassemia phenotype (59). Further studies of the role of tissue specific splicing in determining phenotype in patients such as $\mathrm{AD}$ and $\mathrm{AlNe}$ are planned.

\section{Acknowledgments}

Scott Muir and Stephane Toutain provided expert technical assistance. This research was supported by National Institutes of Health grant DK20902 (to Dr. Hershfield).

\section{References}

1. Hirschhorn, R., G. F. Vawter, J. A. Kirkpatrick Jr., and F. S. Rosen. 1979. Adenosine deaminase deficiency: frequency and comparative pathology in autosomally recessive severe combined immunodeficiency. Clin. Immunol. Immunopathol. 14:107-120.

2. Hirschhorn, R. 1990. Adenosine deaminase deficiency. Immunodefic. Rev. 2:175-198.

3. Hershfield, M. S., and B. S. Mitchell. 1994. Immunodeficiency diseases caused by adenosine deaminase deficiency and purine nucleoside phosphorylase deficiency. In The Molecular and Metabolic Basis of Inherited Disease. 7th edition. C. R. Scriver, A. L. Beaudet, W. S. Sly, and D. Valle, editors. McGraw-Hill, Inc., New York. In press. 
4. Coleman, M. S., J. Donofrio, J. J. Hutton, L. Hahn, A. Daoud, B. Lampkin, and J. Dyminski. 1978. Identification and quantitation of adenine deoxynucleotides in erythrocytes of a patient with adenosine deaminase deficiency and severe combined immunodeficiency. J. Biol. Chem. 253:1619-1626.

5. Cohen, A., R. Hirschhorn, S. D. Horowitz, A. Rubinstein, S. H. Polmar, R. Hong, and D. W. Martin, Jr. 1978. Deoxyadenosine triphosphate as a potentially toxic metabolite in adenosine deaminase deficiency. Proc. Natl. Acad. Sci. USA. $75: 472-475$.

6. Hershfield, M. S. 1979. Apparent suicide inactivation of human lymphoblast S-adenosylhomocysteine hydrolase by 2'-deoxyadenosine and adenine arabinoside: a basis for direct toxic effects of analogs of adenosine. J. Biol. Chem. 254:22-25.

7. Hershfield, M. S., N. M. Kredich, D. R. Ownby, H. Ownby, and R. Buckley. 1979. In vivo inactivation of erythrocyte S-adenosylhomocysteine hydrolase by 2 '-deoxyadenosine in adenosine deaminase-deficient patients. $J$. Clin. Invest. 63:807-811.

8. Hirschhorn, R. 1993. Overview of biochemical abnormalities and molecular genetics of adenosine deaminase deficiency. Pediatr. Res. 33(Suppl.):S35S41.

9. Geffner, M. E., E. R. Stiehm, D. Stephure, and M. J. Cowan. 1986. Probable autoimmune thyroid disease and combined immunodeficiency disease. $A m$. J. Dis. Child. 140:1194-1196.

10. Levy, Y., M. S. Hershfield, C. Fernandez-Mejia, S. H. Polmar, D. Scudiery, M. Berger, and R. U. Sorensen. 1988. Adenosine deaminase deficiency with late onset of recurrent infections: Response to treatment with polyethylene glycol-modified adenosine deaminase (PEG-ADA). J. Pediatr. 113:312-317.

11. Hershfield, M. S., R. H. Buckley, M. L. Greenberg, A. L. Melton, R. Schiff, C. Hatem, J. Kurtzberg, M. L. Markert, R. H. Kobayashi, A. L. Kobayashi, et al. 1987. Treatment of adenosine deaminase deficiency with polyethylene glycol-modified adenosine deaminase. $N$. Engl. J. Med. 316:589-596.

12. Hershfield, M. S., S. Chaffee, and R. U. Sorensen. 1993. Enzyme replacement therapy with PEG-ADA in adenosine deaminase deficiency: overview and case reports of three patients, including two now receiving gene therapy. Pediatr Res. 33(Suppl.):S42-S48.

13. Arredondo-Vega, F. X., J. Kurtzberg, S. Chaffee, I. Santisteban, E. Reisner, M. S. Povey, and M. S. Hershfield. 1990. Paradoxical expression of adenosine deaminase in $\mathrm{T}$ cells cultured from a patient with adenosine deaminase deficiency and combined immunodeficiency. J. Clin. Invest. 86:444-452.

14. Sambrook, J., E. F. Fritsch, and T. Maniatis. 1989. Molecular Cloning: A Laboratory Manual. Cold Spring Harbor Laboratory Press, Cold Spring Harbor, NY.

15. Erlich, H. A. 1989. PCR Technology: Principles and Applications for DNA Amplification. Stockton Press, New York.

16. Innis, M. A., D. H. Gelfand, J. J. Sninsky, and T. J. White. 1990. PCR Protocols: A Guide to Methods and Applications. Academic Press, Inc., San Diego, CA.

17. Higuchi, R. 1989. Simple and rapid preparation of samples for PCR. In PCR Technology. H. A. Erlich, editors. Stockton Press, New York. 31-38.

18. Badley, J. E., G. A. Bishop, T. St. John, and J. A. Frelinger. 1988. A simple, rapid method for the purification of poly $\mathrm{A}^{+} \mathrm{RNA}$. Biotechniques. 6:114116.

19. Wiginton, D. A., G. S. Adrian, and J. J. Hutton. 1984. Sequence of human adenosine deaminase cDNA including the coding region and a small intron. Nucleic Acids Res. 12:2439-2446.

20. Wiginton, D. A., D. J. Kaplan, J. C. States, A. L. Akeson, C. M. Perme, I. J. Bilyk, A. J. Vaughn, D. L. Lattier, and J. J. Hutton. 1986. Complete sequence and structure of the gene for human adenosine deaminase. Biochemistry. 25:8234-8244.

21. Ammann, A. J., M. J. Cowan, D. W. Martin, and D. W. Wara. 1983. Dipyridamole and intravenous deoxycytidine therapy in a patient with adenosine deaminase deficiency. In Primary Immunodeficiency Diseases, March of Dimes Birth Defects. R. J. Wedgwood, F. S. Rosen, and N. W. Paul, editors. Alan R Liss, Inc., New York. 117-120.

22. Cowan, M. J., D. W. Wara, and A. J. Ammann. 1985. Deoxycytidine therapy in two patients with adenosine deaminase deficiency and severe immunodeficiency disease. Clin. Immunol. Immunopathol. 37:30-36.

23. Girault, D., F. Le Deist, M. Debré, J. L. Pérignon, C. Herbelin, C. Griscelli, D. Scudiery, M. Hershfield, and A. Fischer. 1992. Traitement du deficit en adenosine deaminase par l'adenosine desaminase couplee au polyethylene glycol (PEG-ADA). Arch. Fr. Pediatrie 49:339-343.

24. Ochs, H. D., R. H. Buckley, R. H. Kobayashi, A. L. Kobayashi, R. U. Sorensen, S. D. Douglas, B. L. Hamilton, and M. S. Hershfield. 1992. Antibody responses to bacteriophage $\varnothing \times 174$ in patients with adenosine deaminase deficiency. Blood. 80:1163-1171.

25. Padgett, R. A., P. J. Grabowski, M. M. Konarska, S. Seiler, and P. A. Sharp. 1986. Splicing of messenger RNA precursors. Annu. Rev. Biochem. 55:1119-1150.

26. Shapiro, M. B., and P. Senapathy. 1987. RNA splice junction of different classes of eukaryotes: sequence statistics and functional implications in gene expression. Nucleic Acids Res. 15:7155-7174.
27. Losson, R., and F. Lacroute. 1979. Interference of nonsense mutations with eukaryotic messenger RNA stability. Proc. Natl. Acad. Sci. USA. 76:51345137.

28. Baumann, B., M. J. Potash, and G. Kohler. 1985. Consequences of frameshift mutations at the immunoglobulin heavy chain locus of the mouse. EMBO (Eur. Mol. Biol. Organ.) J. 4:351-359.

29. Urlaub, G., P. J. Mitchell, C. J. Ciudad, and L. A. Chasin. 1989. Nonsense mutations in the dihydrofolate reductase gene affect RNA processing. Mol. Cell. Biol. 9:2868-2880.

30. Mashima, Y., A. Murakami, R. G. Weleber, N. G. Kennaway, L. Clarke, T. Shiono, and G. Inana. 1992. Nonsense-codon mutations of the ornithine aminotransferase gene with decreased levels of mutant mRNA in gyrate atrophy. $\mathrm{Am}$. J. Hum. Genet. 51:81-91.

31. Hirschhorn, R. 1993. Identification of two new missense mutations (R156C and S291L) in two ADA-SCID patients unusual for response to therapy with partial exchange transfusions. Hum. Mutat. 1:166-168.

32. Hirschhorn, R., V. Chakravarti, J. Puck, and S. D. Douglas. 1991. Homozygosity for a newly identified missense mutation in a patient with very severe combined immunodeficiency due to adenosine deaminase deficiency (ADASCID). Am. J. Hum. Genet. 49:878-885.

33. Treisman, R., N. J. Proudfoot, M. Shander, and T. Maniatis. 1983. A single base change at a splice site in a beta-thalassemic gene causes abnorma RNA splicing. Cell. 29:903-911.

34. Wieringa, B., F. Meyer, J. Reiser, and C. Weissman. 1983. Unusual splice sites revealed by mutagenic inactivation of an authentic splice site of the rabbit $\beta$-globin gene. Nature (Lond.). 301:38-43.

35. Kuivaniemi, H., S. Kontusaari, G. Tromp, M. Zhao, C. Sabol, and D. J. Prokop. 1990. Identical G +1 to A mutations in three different introns of the Type III procollagen gene (COL3A1) produce different patterns of RNA splicing in 3 variants of Ehlers-Danlos syndrome. IV. An explanation for exon skipping with some mutations and not others. J. Biol. Chem. 265:12067-12074.

36. Hirschhorn, R., A. S. Chen, A. Israni, D. R. Yang, and M. L. Huie. 1993 Two new mutations at the ADA locus (Q254X and del nt955-959) unusual for not being missense mutations. Hum. Mutat. In press.

37. Coulondre, C., J. H. Miller, P. J. Farabaugh, and W. Gilbert. 1978. Molecular basis of base substitution hotspots in Escherichia coli. Nature (Lond.) 274:775-780.

38. Cooper, D. N., and H. Youssoufian. 1988. The CpG dinucleotide and human genetic disease. Hum. Genet. 78:151-155.

39. Bonthron, D. T., A. F. Markham, D. Ginsberg, and S. H. Orkin. 1985. Identification of a point mutation in the adenosine deaminase gene responsible for immunodeficiency. J. Clin. Invest. 76:894-897.

40. Uberti, J., J. J. Lightbody, J. W. Wolf, J. A. Anderson, R. H. Reid, and R. M. Johnson. 1978. The effect of adenosine on mitogenesis of ADA-deficient lymphocytes. Clin. Immunol. Immunopathol. 10:446-458.

41. Uberti, J., W. D. Peterson Jr, J. J. Lightbody, and R. M. Johnson. 1983. A phenotypically normal revertant of an adenosine deaminase-deficient lymphoblast cell line. J. Immunol. 130:2866-2870.

42. Akeson, A. L., D. A. Wiginton, M. R. Dusing, J. C. States, and J. J. Hutton. 1988. Mutant human adenosine deaminase alleles and their expression by transfection into fibroblasts. J. Biol. Chem. 263:16291-16296.

43. Daar, I. O., and L. E. Maquat. 1988. Premature translation termination mediates triosephosphate isomerase mRNA degradation. Mol. Cell. Biol. 8:802813.

44. Chang, Z. Y., P. Nygaard, A. C. Chinault, and R. E. Kellems. 1991. Deduced amino acid sequence of Escherichia coli adenosine deaminase reveals evolutionarily conserved amino acid residues: implications for catalytic function. Biochemistry. 30:2273-2280.

45. Wilson, D. K., F. B. Rudolph, and F. A. Quiocho. 1991. Atomic structure of adenosine deaminase complexed with a transition-state analog: understanding catalysis and immunodeficiency mutations. Science (Wash. DC). 252:12781284

46. Krawczak, M., and D. N. Cooper. 1991. Gene deletions causing human genetic disease: mechanisms of mutagenesis and the role of the local DNA sequence environment. Hum. Genet. 86:425-441.

47. Green, M. R. 1991. Biochemical mechanisms of constitutive and regulated pre-mRNA splicing. Annu. Rev. Cell Biol. 7:559-599.

48. Goguel, V., and M. Rosbash. 1993. Splice site choice and splicing effciency are positively influenced by pre-mRNA intramolecular base pairing in yeast. Cell. 72:893-901.

49. McInnes, B., M. Potier, N. Wakamatsu, S. B. Melancon, M. H. Klavins, S. Tsuji, and D. J. Mahuran. 1992. An unusual splicing mutation in the HEXB gene is associated with dramatically different phenotypes in patients from different racial backgrounds. J. Clin. Invest. 90:306-314.

50. Berkvens, T. M., F. Schoute, H. van Ormondt, P. Meera Khan, and A. J. van der Eb. 1988. Adenosine deaminase gene expression is regulated posttranscriptionally in the nucleus. Nucleic Acids Res. 16:3255-3268.

51. Carstens, R. P., W. A. Fenton, and L. R. Rosenberg. 1991. Identification of RNA splicing errors resulting in human ornithine transcarbamylase deficiency. Am. J. Hum. Genet. 48:1105-1114. 
52. Marvit, J., A. G. DiLella, K. Brayton, F. D. Ledley, K. J. H. Robson, and S. L. C. Woo. 1987. GT to AT transition at a splice donor site causes skipping of the preceding exon in phenylketonuria. Nucleic Acids Res. 15:5613-5628.

53. Weil, D., M. Bernard, N. Combates, M. K. Wirtz, D. W. Hollister, B. Steinman, and F. Ramirez. 1988. Identification of a mutation that causes exon skipping during collagen pre-mRNA splicing in an Ehlers-Danlos syndrome variant. J. Biol. Chem. 263:8561-8564.

54. Kishimoto, T. K., K. O’Connor, and T. A. Springer. 1989. Leukocyte adhesion deficiency: aberrant splicing of a conserved integrin sequence causes a moderate deficiency phenotype. J. Biol. Chem. 264:3588-3595.

55. Hidaka, Y., T. D. Palella, T. E. O’Toole, S. A. Tarle, and W. N. Kelley. 1987. Human adenine phosphoribosyltransferase: identification of allelic mutations at the nucleotide level as a cause of complete deficiency of the enzyme. $J$. Clin. Invest. 80:1409-1415.

56. Andrews, L. G., and M. L. Markert. 1992. Exon skipping in purine nucleoside phosphorylase mRNA processing leading to severe immunodeficiency. J. Biol. Chem. 267:7834-7838.
57. Grandchamp, B., C. Picat, F. de Rooji, C. Beaumont, P. Wilson, J. C. Deybach, and Y. Nordmann. 1989. A point mutation G-A in exon 12 of the porphobilinogen deaminase gene results in exon skipping and is responsible for acute intermittent porphyria. Nucleic Acids Res. 15:6637-6649.

58. Robberson, B. L., G. J. Cote, and S. M. Berget. 1990. Exon definition may facilitate splice site selection in RNAs with multiple exons. Mol. Cell. Biol. 10:8494.

59. Treisman, R., S. H. Orkin, and T. Maniatis. 1983. Specific transcription and RNA splicing defects in five cloned $\beta$-thalassemia genes. Nature (Lond.). 302:591-596.

60. Krainer, A. R., T. Maniatis, B. Ruskin, and M. R. Green. 1984. Normal and mutant human $\beta$-globin pre-mRNAs are faithfully and efficiently spliced in vitro. Cell. 36:993-1005.

61. Hirschhorn, R., A. Ellenbogen, and S. Tzall. 1992. Five missense mutations at the adenosine deaminase locus (ADA) detected by altered restriction fragments and their frequency in ADA- patients with severe combined immunodeficiency (ADA-SCID). Am. J. Med. Genet. 42:201-207. 